This item was submitted to Loughborough's Research Repository by the author.

Items in Figshare are protected by copyright, with all rights reserved, unless otherwise indicated.

\title{
Detecting phenology change in the mayfly Ephemera danica: responses to spatial and temporal water temperature variations
}

PLEASE CITE THE PUBLISHED VERSION

http://dx.doi.org/10.1111/een.12164

\section{PUBLISHER}

Wiley Publishing / ( T) The Royal Entomological Society

VERSION

AM (Accepted Manuscript)

\section{PUBLISHER STATEMENT}

This work is made available according to the conditions of the Creative Commons Attribution-NonCommercialNoDerivatives 4.0 International (CC BY-NC-ND 4.0) licence. Full details of this licence are available at: https://creativecommons.org/licenses/by-nc-nd/4.0/

\section{LICENCE}

CC BY-NC-ND 4.0

\section{REPOSITORY RECORD}

Everall, Nicholas C., Matthew F. Johnson, Robert L. Wilby, and Cyril J. Bennett. 2019. "Detecting Phenology Change in the Mayfly Ephemera Danica: Responses to Spatial and Temporal Water Temperature Variations". figshare. https://hdl.handle.net/2134/17672. 
1 Detecting phenology change in the mayfly Ephemera danica:

2 Responses to spatial and temporal water temperature variations

4 Nicholas C. Everall, ${ }^{1}$ Matthew F. Johnson ${ }^{2}$, Robert L. Wilby ${ }^{2}$ and Cyril J. Bennett ${ }^{1}$

5

$6{ }^{1}$ Aquascience Consultancy, 18 Hawthorne Way, Ashgate, Chesterfield, Derbyshire S42 7JS,

$7 \quad$ UK. Email: rnaquaconsult@aol.com

$8 \quad{ }^{2}$ Department of Geography, Loughborough University, Leicestershire, LE11 3TU, UK.

9 Email: m.f.johnson@lboro.ac.uk; r.l.wilby@lboro.ac.uk

10

11 Corresponding author: Nicholas Everall, rnaquaconsult@aol.com

12

13 Accepted for publication: Ecological Entomology

14 Date of acceptance: 16 September 2014 


\section{Abstract}

17 1. Rising water temperatures under climate change are expected to affect the phenology of 18 aquatic insects, including the mayfly Ephemera danica which is widespread throughout 19 Europe.

2. To assess temporal and spatial variability in mayfly emergence, E. danica were monitored at two thermally contrasting reaches in the River Dove, English Peak District over the period 2007 to 2013. Inter-annual variations in growing degree days (GDDs) were modelled for an upstream site with intermittent spring flow supplementing main channel flow (Beresford Dale) and downstream site dominated by near constant discharges of cool groundwater (Dovedale).

3. A strong association exists between the emergence cycle of E. danica and GDDs at each site. Beresford Dale accumulated on average 374 more GDDs than Dovedale. Following warm summers E. danica emerged after only one year in Beresford Dale but began to revert to a bi-annual cycle after the particularly wet/cool year of 2012. In Dovedale, E. danica maintained a two-year cycle throughout the monitoring period despite the phenology changes observed 8 km upstream.

4. Data from the present study suggest that habitats near cool groundwater may provide important refugia for populations of insects, potentially delaying permanent shifts in phenology under climate change. However, ability to detect changes in the thermal triggers and phenological response may be hindered by conventional spot sampling protocols.

Kewords: Mayfly; Phenology; Water temperature; Emergence; Thermal refugia 
Water temperature (Tw) affects many aspects of aquatic life including the metabolism of animals (e.g. Weatherley \& Ormerod, 1990) and photosynthesis of plants (Berry \& Björkman 1980). Insects are poikilothermic ectotherms so their development and phenology are regulated by ambient temperatures (Raddum \& Fjellheim, 1993; Knispel et al., 2006). Development ceases when Tw is outside upper or lower thresholds, and thermal extremes can cause stress or even mortality (Dallas \& Rivers-Moore, 2012). Consequently, cumulative or growing degree days (GDDs) are often used to relate thermal conditions to organism development (Neuheimer \& Taggart, 2007). GDDs are the number of degrees that exceed a minimum temperature threshold each day, accumulated over the development period or year.

Insect phenology is extremely diverse, often very plastic, and characterised by individuals progressing through multiple, distinct life-stages. Timing of emergence from aquatic larval stage to the sexually mature, terrestrial stage is of particular significance because many insects have only a short window to mate and lay eggs. It is, therefore, important that emergence coincides with favourable weather and is synchronous, both as a population defence against predation and as a means of maximising potential genetic spread (Watanabe et al., 1999; Sparks et al., 2010).

River temperature is spatially heterogeneous and temporally variable (Webb et al. 2008). Water temperatures usually have strong diel and seasonal cycles related to solar forcing, and typically increases with distance downstream. Tributaries and groundwater can interrupt this pattern and create locally distinct thermal regions. For example, phraetic groundwater usually has a relatively constant temperature that reduces diel and seasonal temperature ranges

60 (Constantz, 1998; O’Driscoll \& DeWalle, 2006). 
61 There is evidence that river Tw is changing in response to climate change (van Vliet et al., 2011; Isaak et al., 2012; Orr et al. 2014). In addition, land drainage, alteration of river courses and ponding by weirs, can alter the thermal dynamics of rivers (Caissie, 2006), as can removal of riparian vegetation (e.g. Broadmeadow et al., 2011). Aquatic organisms respond to changing thermal conditions in complex ways (Ward \& Stanford, 1982). Given the dependence of phenology on heat accumulation, emergence of insects is particularly susceptible to changing temperature and can have adverse effects on freshwater insects populations (Harper \& Peckarsky, 2006; Durance and Ormerod, 2007; Thackeray et al., 2010). In this paper, we describe spatial and temporal variability in mayfly emergence in the River Dove, English Peak District. We then assess links between varying Tw and mayfly phenology, and discuss whether conventional monitoring protocols are adequate for detecting changes in the thermal driver and ecological response.

\section{MATERIALS AND METHODS}

Study organism

Ephemera danica Muller, 1764 (Ephemeroptera) is one of the largest mayflies found in the

British Isles with some females reaching over $30 \mathrm{~mm}$. The larvae are burrowing animals and are often found where silt accumulates in rivers. Traditionally E. danica has been reported to emerge after two years in an aquatic nymphal stage and is referred to as a semivoltine species (Wright et al., 1981; Tokeshi, 1985; Elliott et al., 1988). The adult emergence period is normally in late-May and early-June. Tokeshi (1985) found that male E. danica have a minimum growth threshold of $2.6{ }^{\circ} \mathrm{C}$ and require at least 3398 annual GDDs to emerge.

83 Females have a higher minimum growth threshold $\left(3.1^{\circ} \mathrm{C}\right)$ and hence require more GDDs for 
emergence (3631). Differing growth thresholds for males and females is common in mayfly populations (Svensson 1977; Wright et al. 1981).

In controlled laboratory experiments, Bennett (2007) noted that both male and female $E$.

danica can reach maturity in a single year with larvae reaching up to $19 \mathrm{~mm}$ within four months from hatching when Tw averages $20^{\circ} \mathrm{C}$. Bennett (2007) also noted that $E$. danica in the North Wey, Surrey, UK reached maturity in a single year between 1995 and 2002. The current study builds on these observations by examining the life cycle of E. danica from 2007 to 2013 at two contrasting sites in the River Dove, UK.

The River Dove rises on Axe Edge from moorland springs and runs southward for $73 \mathrm{~km}$ through the Peak District National Park before joining the River Trent at Newton Solney. The catchment area upstream of monitoring sites is $131 \mathrm{~km}^{2}$ and elevation ranges from $450 \mathrm{~m}$ at source to $155 \mathrm{~m}$ in Dovedale. Land-use is predominately grazed pasture with isolated stands of deciduous woodland covering 5\% of the catchment. Annual precipitation exceeds 1000 mm. The Dove flows parallel to a Carboniferous limestone outcrop with phraetic springs, which it intersects at Beresford.

Invertebrate and Tw monitoring sites are located in Beresford Dale and Dovedale (Figure 1). Beresford Dale is $20 \mathrm{~km}$ from the source of the Dove, situated at the upstream end of a limestone gorge. Here, intermittent springs discharge water of relatively constant temperature $\left(9-14{ }^{\circ} \mathrm{C}\right)$ during autumn and winter. Dovedale is $9.7 \mathrm{~km}$ downstream of Beresford Dale in a

105 limestone gorge with Ash (Fraxinus excelsior) woodland. Here, groundwater discharges into

106 the river all year-round at $\sim 8.5{ }^{\circ} \mathrm{C}$. The stretch between Beresford and Dovedale is affected 
107 by over 100 weirs ( $<0.5 \mathrm{~m}$ high) installed over a century ago to increase the feeding area for

108 trout. The Environment Agency of England and Wales (EA) have recorded daily discharge at 109 a gauging station in Dovedale since 1969 (Figure 1).

111 Water temperature monitoring and analysis

112 The Loughborough University TEmperature Network (LUTEN) consists of 36 monitoring

113 sites in the Rivers Dove and Manifold. At each site, Gemini Aquatic 2 Tinytag thermistors

114 record the maximum, mean and minimum air and Tw every 15-minutes since March 2011.

115 Tinytag thermistors have a quoted accuracy of $0.2^{\circ} \mathrm{C}$, which has been confirmed under

116 experimental conditions (Johnson \& Wilby, 2013). There are eight LUTEN sites between

117 invertebrate monitoring sites (Figure 1). Sites D16 (Beresford Dale) and D24 (Dovedale) are

118 the closest records. However, D24 has an incomplete record due to sensor failure and as such,

119 D23 is used herein, which records almost identical temperatures to D24 (maximum difference 120 in daily temperature was $0.62{ }^{\circ} \mathrm{C}$ during model calibration and validation period). Full details

121 of LUTEN, the monitoring strategy and data validation can be found in Wilby et al. (2012)

122 and Johnson et al. (2014).

123 The EA takes monthly spot measurements for routine monitoring. To test the ability of this 124 sampling strategy to detect thermal changes one value per month was randomly selected from 125 the 15 minute LUTEN data during typical EA sampling hours (08:00 to 18:00) from June 1262011 to May 2012. These 12 values were then used to estimate the annual mean at site D16.

127 This was repeated 1000 times allowing estimation of the variance in the mean due to daylight 128 sample times, when compared with the 'true' estimate based on the full LUTEN-record. 
129 Water temperatures for the years 2007 to 2013 were hindcast from air temperatures measured

130 at Buxton, Derbyshire ( $\sim 20 \mathrm{~km}$ from study sites and significantly correlated $\left(r^{2}=0.8\right)$ to 3-

131 years of monitored air temperature at each site). Air and water temperature are not directly

132 related but because both are ultimately driven by solar radiation, the latter can be predicted

133 from air temperatures using regression analysis (Stefan and Preud'homme, 1993; Mohseni et

134 al., 1998). We deploy logistic regression models built previously for LUTEN sites and tested

135 under contrasting weather conditions (Johnson et al. 2014; Wilby et al., 2014). These models

136 explained 85\% of the variance in Tw at D16 and 83\% at D23 (Table 1) and have the form:

$137 \quad T w=\frac{\alpha}{\left(1+\exp ^{\gamma(\beta-T a)}\right)}$

138

139 where $\alpha$ is the model asymptote, $\beta$ is the model inflection point and $\gamma$ is the model gradient at

$140 \beta$. Using the same models, a Tw record was constructed for 2005-2013 in order to calculate

141 GDDs using the thresholds of Tokeshi (1985). GDDs were accumulated from 1 June to the 31

142 May each year to match the normal development period of E. danica from egg-laying.

144 Invertebrate sampling

145 Invertebrate monitoring sites were approximately $40 \mathrm{~m}$ long, 7-8 $\mathrm{m}$ wide, and located in 146 riffles. Two sites in Beresford Dale were $100 \mathrm{~m}$ downstream of Hartington bridge and 147 approximately $100 \mathrm{~m}$ apart. The substrate consists of clean, coarse-gravels (median grain size

$148\left[\mathrm{D}_{50}\right]=48 \mathrm{~mm}$ ) and sparse stands of water crowfoot (Ranunculus spp.) with very occasional 149 starwort (Callitriche spp.). The Dovedale site also comprises of clean, coarse-gravels $\left(\mathrm{D}_{50}=41\right.$ $150 \mathrm{~mm}$ ) with sparse weed-beds of water crowfoot (Ranunculus spp.). 
151 All study reaches hold good populations of E. danica based on data collected from previous surveys (Everall, 2010; 2012). E. danica samples were taken from exposed gravels and fine-

153 sediment beneath weed-beds using a $0.1 \mathrm{~m}^{2}$ Surber net sampler fitted with a $2 \mathrm{~cm}$ deep steel

154 curtain. Sampling was undertaken in Aprils 2007, 2010, 2011, 2012 and 2013 following the

155 life-stage techniques of Bennett (2007). The number of E. danica individuals and their body

156 length was recorded by site and year. Mayflies larger than $7 \mathrm{~mm}$ were also sexed; this was

157 not always possible for smaller individuals.

158 In a two-year cycle it is expected that there will be a tri-modal size distribution with separate 159 peaks for male and female adults about to emerge in June, and a third peak of smaller 160 mayflies that require an additional year of growth. Male and female mayflies usually form 161 distinct size classes because of the differing GDDs required for development. In a one year

162 cycle, mayfly samples are expected to have a uni-modal size distribution with the majority 163 about to emerge in June plus a few smaller, over-wintering individuals (Figure 2). Hence, the 164 number of small, unsexed mayfly present each year, and the size difference between males and females, are indicators of the presence of the two-year emergence cycle.

Statistical analysis

SPSS 19.0 was used for all regression analysis. Statistical comparison between the total

169 length of male and female mayflies between and within years was undertaken with Mann-

170 Whitney U tests in SPSS 19.0. 
174 Daily-mean Tw has clear seasonality in Beresford Dale (Figure 3). Year 2006 was the

175 warmest in the monitoring period and amongst the hottest on record in the UK. Hindcast

176 annual mean Tw varied by no more than $1.0^{\circ} \mathrm{C}$ between consecutive years, but GDDs fell

177 between 2006 and 2010 before rising in 2011 and 2012 (Table 2). However, summer GDD

178 increased between 2008 and 2011. Overcast conditions and high discharge resulted in

179 markedly lower summer Tw in 2011-2012 even though the annual GDDs were the second

180 highest. Observed Tw were under-predicted in summer 2011 but over-predicted by the model

181 in 2012, because of the changing significance of spring flow contributions which are not fully

182 replicated by the model (Figure 3). At Dovedale, annual mean Tw was less variable between

183 years and the seasonal range is less than at Beresford due to groundwater inflows (Table 2).

184 Consequently, summer temperatures are relatively cool and there were on average, 260 fewer

185 GDDs each year between 2006 and 2011 (Figure 3). The contrast between Beresford Dale

186 and Dovedale was greatest in the summer. For example, in 2012-2013 there were 266 more

187 GDDs in Beresford Dale of which 231 were due to higher summer temperatures (Table 2).

188 The EA spot sampling yields Tw mean $10.3 \pm 1.1{ }^{\circ} \mathrm{C}(n=12)$ compared with the resampled

189 LUTEN Tw mean $9.5 \pm 0.01{ }^{\circ} \mathrm{C}$ in Beresford Dale (Figure 4), whereas the entire LUTEN

190 record yields Tw mean $9.7 \pm 0.02{ }^{\circ} \mathrm{C}(n=32160)$.

Temporal variations in emergence

193 In 2007, E. danica at Beresford Dale had a tri-modal size distribution, with larger males and

194 females about to emerge plus a third group of smaller mayflies (Figure 5a). Monitoring in 2010 revealed a uni-modal size distribution indicating a single year cohort (Figure 5b). Mayfly with body length $>22 \mathrm{~mm}$ may be a remnant cohort of second year females. However,

197 the lack of a second generation indicated by smaller, unsexed individuals, and lack of size 
distinction between the sexes, suggest emergence mostly within one year of hatching. This pattern continued in 2011 and 2012 with few small ( $<10 \mathrm{~mm}$ ) mayflies (Figure 5b).

In 2013, the nymph populations in Beresford Dale appeared to be reverting back to a two year, tri-modal size distribution (Figure $5 \mathrm{~b})$. The presence of small individuals $(<8 \mathrm{~mm})$ suggests over-wintering mayflies and the greater distinctiveness between males and females is indicative of a two year cohort (Table 3). This apparent reversion back to a two-year cycle coincides with the cool summer and low GDDs of the previous year (Figure 6a).

In 2011, adult male and female mayflies were on average $11.1 \mathrm{~mm}$ and $11.5 \mathrm{~mm}$ long, respectively (compared with $18.0 \mathrm{~mm}$ and $23.7 \mathrm{~mm}$ in 2007). This is statistically different in both cases (Mann-Whitney $\mathrm{U} ; p<0.001$ ) (Figure 6). The distribution of mayfly sizes was also significantly different between years, indicated by Levene’s tests $(p<0.001$ for both males and females), with 2007 populations of male and female being less varied than in 2010 and 2011. In Beresford Dale, females were significantly larger than males within all years, except 2011 when sexes were statistically similar (see Table 3 for $p$-values). In Dovedale,

212 females were statistically distinct from males in both years.

213 The one year cohorts between 2010 and 2012 coincided with warmer summers and the return 214 to a bi-annual cohort in 2013 with the unusually cool summer of 2012. As expected, the 215 average size depends on the number of GDDs over the preceding year with mayfly larger when emerging after a warm year (Figure 6). In addition, mayflies developing in one year are

217 generally smaller than those with a two year generation because more GDDs are accumulated 218 over two moderately warm years than one very warm year. However, the relatively warm 219 year 2011 produced large mayfly, despite the fact that the population had a one year generation period (Figure 6). 
223 The E. danica population in Dovedale is unlike that in Beresford Dale during the same year

224 (Figure 7). Populations in Dovedale retained a large number of small, unsexed mayfly in 2252012 and 2013, in comparison to none (2012) and six (2013) in Beresford. Males and females 226 also formed distinct size classes, in contrast to Beresford Dale where there was substantial 227 overlap (although in 2013 there was some divergence between size of males and females).

E. danica sampled in Dovedale were generally larger than those in Beresford even though male mayflies in Dovedale were exposed on average to 374 fewer GDDs between 2005 and 2011. However, the contrast in thermal regime between the two sites was reduced in 20122013 when Dovedale had 266 fewer GDDs (Table 2). It should also be noted that because mayflies in Dovedale retained two year generations, they actually accumulated substantially more GDDs than those in the warmer sites of Beresford.

\section{DISCUSSION}

\section{Plasticity in phenology}

236 In 2007 at Beresford Dale, E. danica nymphs entering a second year largely accounted for 237 good recruitment the following year but, by 2010-2012 the mayfly population appeared to be 238 supplemented by nymphs reaching maturity in a single year. This is consistent with studies of

239 E. danica in southern England chalk streams showing that both males and females can reach 240 maturity in a single year depending on Tw (Bennett, 2007). Field data from the River Dove suggests that summer maximum temperatures above $15{ }^{\circ} \mathrm{C}$ result in $E$. danica moving towards a one year cohort. These results are consistent with temperature thresholds in both

243 field and laboratory studies (Bennett, 2007). Thermal dynamics in the River Dove were 244 related to changing river flow during the monitoring period with high summer temperatures 
in 2011 associated with drought conditions and low temperatures in 2012 with exceptionally wet conditions (Parry et al. 2013). Other studies have tested the phenological response of mayfly (Baetis bicaudatus) to both temperature and discharge and found that temperature accelerated emergence but flow had no impact (Harper \& Peckarsky 2006).

E. danica phenology in the River Dove appears to be plastic, changing temporally from yearto-year. GDDs proved more useful in generalising thermal regimes than annual mean temperature. River temperatures in preceding summer and autumn strongly determine subsequent emergence patterns. Bennett (2007) also found that summer-autumn was the critical period influencing $E$. danica development and summer temperatures have been identified as significant to other mayfly species (Ephoron shigae, Watanabe et al., 1999) and insect groups including stonefly, caddisfly and beetles (Haidekker \& Hering 2008; Li et al., 2011). As far as the authors are aware, the apparent change in E. danica populations in the River Dove from a one year cycle in 2012 back to two year cycle in 2013 is the first documented evidence of a reversal in mayfly phenology related to Tw. This reversal was associated with cooler summer (and annual) Tw in Beresford Dale. In other words, a shortterm reduction in thermal exposure coincided with a phenology reversal in E. danica.

Mayflies grew larger, more were caught, and there was greater distinctiveness in size between the sexes when exposed to higher GDDs. Conversely, mayflies were smaller, less numerous and the size of males and females were more alike when developing over fewer GDDs. However, this relationship was complicated because fewer GDDs were accumulated when developing over a single hot year in comparison to two cooler years. Consequently, mayflies emerging in a one-year cycle, associated with warm years, were smaller than those emerging after two relatively cool years, consistent with the findings of Bennett (2007). 
270 The phenology of many insect species has been related to temperature, in terms of timing of 271 emergence, size of emerging individuals, and generation period (see Thackeray et al., 2010). 272 Phenology changes could be of significance because populations with single year cycle are potentially more vulnerable to adverse weather when the majority of the population is in terrestrial, adult form (Bennett, 2007). For example, prolonged high winds and heavy rain during the main emergent period in 2000 prevented female E. danica with a mainly one-year generation on the River Wey, Surrey from returning to the water to lay eggs (Bennett \& Gilchrist, 2010). As a result, the larval population was much reduced the following year, whereas a large population remained in the River Test in Hampshire where larvae had maintained a predominately two year cycle (Bennett \& Gilchrist, 2010). In other words, populations with a two year cycle have a reserve of over-wintering individuals that supplement emergence in the following year.

Water temperature has also been related to the size and fecundity of adults in a number of species (see reviews in Honêk 1993; Blanckenhorn, 2005). Consequently, altering the growth, development and size of insects may impact population dynamics by affecting reproductive success. Hence, smaller mayflies emerging from a one year cycle in the Dove are likely to have less reproductive success than larger mayflies emerging after two years development. This has been confirmed in E. danica by Bennett (1996) who found smaller females produced fewer eggs than larger individuals: 6000 in $24 \mathrm{~mm}$ females, compared with 3000 in $18 \mathrm{~mm}$

289 females. Consequently, mayflies in the River Dove at Beresford in 2010 and 2011 are likely to have produced fewer than half the eggs of mayfly in Dovedale over the same time period.

291 Given the dependence of insect development on heat accumulation through larval stages, it is likely that phenology changes have occurred during warm periods in the climate record. 
293 However, the negative connotations associated with one-year emergence cycles combined

294 with long-term warming of freshwaters (particularly in summer) suggests that anthropogenic

295 climate change could have adverse impacts on mayfly phenology. In addition, the differing 296 size and abundance of mayfly between years could affect trophic relationships, altering food 297 availability and food-web dynamics. However, the spatial heterogeneity in mayfly phenology

298 in the Dove might act to buffer against mayfly shortages at a site because predatory birds and 299 fish could move to other sites where mayfly populations may be larger.

\section{Management of thermal refugia}

E. danica populations at sites A and B (separated by $300 \mathrm{~m}$ ) in Beresford Dale were very similar. However, the phenology of mayflies from Beresford Dale and Dovedale (separated by $8.4 \mathrm{~km}$ ) were substantially different. Dovedale is fed by considerable groundwater inflows, which lower mean Tw with dampened seasonal and diel cycles (Johnson et al. 2014). The cooler water of the River Dove (especially in summer) appears to have provided a thermal refuge where E. danica phenology has remained unchanged compared to Beresford Dale. Such areas could be of critical ecological significance in the context of climate change because they could delay changes in insect phenology. Conversely, warming reaches could experience substantial changes in phenology.

311 Given the implications of rising Tw for insect populations, it is important to understand and

312 attempt to manage river temperatures. Spot sampling of daytime Tw 12-times a year, 313 following the sampling strategy of the EA, over-estimated annual mean Tw relative to 314 continuous monitoring and the standard error of the EA estimate $\left(1.1^{\circ} \mathrm{C}\right)$ is comparable to 315 the difference between warmest and coolest years in the LUTEN hindcast series $\left(1.6^{\circ} \mathrm{C}\right)$. It is 316 further recognised that any creep in spot sampling time, for example, from early-morning to 
midday, could artificially increase Tw estimates (Toone et al. 2011). Moreover, annual Tw

318 were poor indicators of thermal regime relevant to $E$. danica, as summer Tw was of greater

319 importance. Consequently, spot sampling would have been insufficient to resolve differences

320 in thermal regime between years or sites. Higher resolution sampling is needed to relate

321 ecological changes to $\mathrm{Tw}$, at least accounting for seasonal variations in temperature and preferably including sub-daily temperature changes which may be relevant to nocturnal fauna

323 (Wilby et al., 2014). Reliable, sub-daily resolution temperatures can now be obtained via robust, field-deployable thermistors.

Regulatory bio-monitoring in the UK typically involves identifying invertebrates to family level for water quality and ecological assessment (Murray-Bligh, 1999; Environment Agency, 2009). Given the species-specificity of insect-temperature relationships it is important that finer resolution information is obtained when evaluating the impacts of changing thermal regime on invertebrates. Furthermore, monitoring schemes usually focus on invertebrate community composition (Paisley et al., 2007). Whilst Tw may alter community composition, this is likely to be preceded by shifts in the growth, development and phenology of insects. Consequently, consideration of insect size and sex ratios within species would allow the identification of thermal effects before the loss of species from the community pool. Such metrics could be used for early climate change detection.

\section{CONCLUSIONS}

337 The phenology of E. danica was found to be highly plastic in the River Dove due to variations in summer Tw over the years 2007-2013. In addition, E. danica phenology varied between sites with and without permanent groundwater inflows. Changes in phenology can be detrimental to insect populations because of reduced fecundity and increased vulnerability 
341 to adverse weather. Annual mean Tw can mask important thermal characteristics, particularly

342 increasing summer temperatures, which correlate with E. danica emergence. In addition,

343 high-resolution invertebrate monitoring (size of individuals within an individual species) was

344 required to identify the impacts of changing Tw on E. danica populations. Routine, coarse-

345 scale biomonitoring is unlikely to have detected such trends. An unusually cool summer in

3462012 returned mayfly phenology to a two-year cycle. Consequently, the protection of thermal

347 refugia (such as those areas where phraetic groundwater or riparian shade buffers against

348 solar forcing) could buffer against phonological change in insects subject to rising Tw under

349 climate change. In addition, artificial creation or enhancement of thermal refugia by riparian

350 shade management could delay, or even reverse, changes to the phenology of some species

351 otherwise impacted by higher water temperatures.

352

353 ACKNOWLEDGEMENTS

354 The authors wish to thank The Wild Trout Trust, Beresford Fishery, Derbyshire County

355 Angling Club, Peak District National Park Authority and Staffordshire Wildlife Trust for

356 part-funding this work. The opinions expressed by the authors do not necessarily reflect those

357 of the aforementioned organisations. The manuscript was improved in response to the helpful

358 comments of two anonymous reviewers.

\section{Contribution of authors}

361 Everall and Johnson designed the project. Everall and Bennett collected and analysed

362 invertebrate data. Johnson and Wilby collected and analysed temperature data. All authors

363 contributed to paper writing. 


\section{REFERENCES}

366 Bennett CJ. (1996) The ecology of mayflies (Ephemeroptera) in the upper reaches of the

367 River Wey in Surrey. PhD thesis, University of London, UK (unpublished).

368 Bennett CJ. (2007) The ecology of a seven year study of the life cycle of the mayfly 369 Ephemera danica. Freshwater Forum 27: 3-14.

370 Bennett CJ, Gilchrist W. (2010) Riverflies. In: Maclean, N. (ed) Silent Summer. Cambridge

371 University Press, UK. pp. 401-414.

372 Berry J, Bjorkman O. (1980) Photosynthetic response and adaptation to temperature in higher 373 plants. Annual Review of Plant Physiology 31: 491-543.

374 Blanckenhorn WU. (2005) Behavioral causes and consequences of sexual dimorphism. 375 Ethology 111: 977-1016.

376 Broadmeadow SB, Jones JG, Langford TEL, Shaw PJ, Nisbet TR. (2011) Influence of 377 riparian shade on lowland stream water temperatures in southern England and their viability 378 for brown trout. River Research and Applications 27: 226-237.

379 Caissie D. (2006) The thermal regime of rivers: a review. Freshwater Biology 51: 1389-1406.

380 Constantz J. (1998) Interaction between stream temperature, streamflow, and groundwater 381 exchanges in alpine streams. Water Resources Research 34: 1609-1615.

382 Dallas HF, Rivers-Moore NA. (2012) Critical thermal maxima of aquatic macroinvertebrates: 383 towards identifying bioindicators of thermal alteration. Hydrobiologia 679: 61-76. 
Durance I, Ormerod SJ. (2007) Climate change effects on upland stream macroinvertebrates 385 over a 25-year period. Global Change Biology 13: 942-957.

386 Elliott JM, Humpesch UH, Macan TT. (1988) Larvae of the British Ephemeroptera. A key 387 with ecological notes. Scientific Publication No. 49. Freshwater Biological Association. 388 Ambleside.

Environment Agency (2009) Freshwater Macro-invertebrate Analysis of Riverine Samples.

390 Operational Instruction 024_08. Environment Agency, UK.

391 Everall NC. (2010) The aquatic ecological status of the rivers of the Upper Dove Catchment 392 in 2009. Natural England Commissioned Report NECR046. Natural England: Sheffield.

393 Everall NC, Farmer A, Heath AF, Jacklin TE, Wilby RL. (2012). Ecological benefits of 394 creating messy rivers. Area 44: 470-478.

395

Gurnell A, Tockner K, Edwards P, Petts G. (2005) Effects of deposited wood on 396 biocomplexity of river corridors. Frontiers in Ecology and Environment 3: 377-382.

397 Haidekker A, Herring D. (2008) Relationship between benthic insects (Ephemeroptera, 398 Plecoptera, Coleoptera, Trichoptera) and temperature in small and medium-sized streams in 399 Germany: A multivariate study. Aquatic Ecology 42: 463-481.

400 Harper MP, Perckarsky BL. (2006) Emergence cues of a mayfly in a high-altitude stream 401 ecosystem: Potential response to climate change. Ecological Applications 16: 612-621.

402 Honêk A. (1993) Intraspecific variation in body size and fecundity in insects: a general 403 relationship. Oikos 66: 483-492. 
404 Imholt C, Gibbins CN, Malcolm LA, Langan S, Soulsby C. (2010) Influence of riparian 405 cover on stream temperatures and the growth of the mayfly Baetis rhodani in an upland 406 stream. Aquatic Ecology 44: 669-678.

407 Isaak DJ, Wollrab S, Horan D, Changler G. (2012) Climate change effects on stream and 408 river temperatures across the northwest U.S. from 1980-2009 and implications for 409 salmonid fishes. Climate Change 113: 499-524.

410 Johnson MF, Wilby RL. (2013) Shield or not to shield: Effects of solar radiation on water 411 temperature sensor accuracy. Water 5: 1622-1637.

412 Johnson MF, Wilby RL, Toone JA. (2014) Inferring air-water temperature relationships 413 from river and catchment properties. Hydrological Processes 28: 2912-2928.

414 Knispel S, Sartori M, Brittain JE. (2006) Egg development in the mayflies of a Swiss glacial 415 floodplain. Journal North American Benthological Society 25: 2, 430-443.

416 Li JL, Johnson SL, Sobota JB. (2011) Three responses to small changes in stream 417 temperature by autumn-emerging aquatic insects. Journal of the North American 418 Benthological Society 30: 474-484.

419 Mohensi O, Stefan HG, Erickson TR. (1998) A nonlinear regression model for weekly stream 420 temperatures. Water Resources Research 34: 2685-2692.

421 Murray-Bligh JAD. (1999) Procedure for collecting and analysing macro-invertebrate 422 samples. Quality Management Systems for Environmental Biology: Biological Techniques, 423 BT001 Version 2.0. Bristol: Environment Agency.

424 Neuheimer AB, Taggart CT. (2007) The growing degree-day and fish size-at-age: the 425 overlooked metric. Canadian Journal of Fisheries and Aquatic Science 64: 375-385. 
426 O’Driscoll MA, DeWalle DR. (2006) Stream-air temperature relations to classify stream427 ground water interactions in a karst setting, central Pennsylvania, USA. Journal of Hydrology 428 329: 140-153.

429 Paisley MF, Trigg DJ, Walley WJ. (2007) Revision and Testing of BMWP scores. Final 430 report SNIFFER Project WFD72a. Edinburgh, UK.

431 Parry S, Marsh T, Kendon M. (2013) 2012: from drought to floods in England and Wales. 432 Weather 68: 268-274.

433 Raddum GG, Fjellheim A. (1993) Life-cycle and production of Baetis-Rhodani in a regulated 434 river in Western Norway-comparison of pre-regulation and post-regulation conditions. 435 Regulatory Rivers Reservoir Management 8: 49-61.

436 Sparks TH, Preston CD, Roy DB. (2010) Climate Change. In: Silent Summer The State of 437 Wildlife in Britain and Ireland. Ed. N. Maclean. Cambridge University Press, 765pp.

438 Stefan HG, Preud'homme EB. (1993) Stream temperature estimation from air temperature. 439 Water Resource Research 29: 27-45.

440 Svensson B. (1977) Life cycle, energy fluctuations and sexual differentiation in Ephemera 441 Danica (Ephemeroptera), a stream-living mayfly. Oikos 29: 78-86.

442 Thackeray SJ, Sparks TH, Frederiksen M, Burthes S, Bacon PJ, Bell JR, Botham MS, 443 Brereton TM, Bright PW, Carvalho L, Clutton-Brock T, Dawsons A, Edwards M, Elliott M, 444 Harrington R, Johns D, Jones ID, Jones JT, Leech DI, Roy DB, Scott WA, Smith M, 445 Smithers RI, Winfield IJ, Wanless S. (2010) Trophic level asynchrony in rates of 446 phonological change for marine, freshwater and terrestrial environments. Global Change 447 Biology 16: 3304-3313. 
448 Tokeshi M. (1985) Life-cycle and production of the burrowing mayfly, Ephemera danica: a 449 new method of estimating degree-days for growth. Journal of Animal Ecology 54: 919-930.

450 Toone JA, Wilby RL, Rice SP. (2011) Surface-water temperature variations and river 451 corridor properties. Water Quality: Current Trends and Expected Climate Change Impacts 452 Proceedings of symposium H04 held during IUGG2011 in Melbourne, Australia, July 2011. 453 IAHS Publication 348; 129-134.

454 van Vliet MTH, Ludwig F, Zwolsman JJG, Weedon GP, Kabat P. (2011) Global river 455 temperatures and sensitivity to atmospheric warming and changes in river flow. Water 456 Resources Research 47: 10.1029/2010WR009198.

457 Ward JV, Stanford JA. (1982) Thermal responses in the evolutionary ecology of aquatic 458 insects. Annual Review of Entomology 27: 97-117.

Watanabe NC, Mori I, Yoshitaka I. (1999). Effect of water temperature on the mass 460 emergence of the mayfly, Ephoron shigae, in a Japanese river (Ephemeroptera: 461 Polymitarcyidae). Freshwater Biology 41: 537-541.

462 Weatherly NS, Ormerod SJ. (1990). Forest temperatures of upland streams in Wales: a 463 modelling exploration of the biological effects. Freshwater Biology 24: 109-122.

464 Webb BW, Hannah DM, Moore RD, Brown LE, Nobilis F. (2008) Recent advances in stream 465 and river temperature research. Hydrological Processes 22: 902-918.

466 Wilby RL, Orr H, Watts G, Battarbee RW, Berry PM, Chadd R, Dugdale SJ, Dunbar MJ, 467 Elliott JA, Extence C, Hannah DM, Holmes N, Johnson AC, Knights B, Milner NJ, Ormerod 468 SJ, Solomon D, Timlett R, Whitehead PJ, Wood PJ. (2010). Evidence needed to manage 
469 freshwater ecosystems in a changing climate: Turning adaptation principles into practice. $470 \quad$ Science of the Total Environment 408: 4150-4164.

471 Wilby RL, Johnson MF, Toone JA. (2012) The Loughborough University TEmperature 472 Network (LUTEN): Rationale and analysis of stream temperature variations. Proceedings of 473 Earth Systems Engineering 2012: Systems Engineering for Sustainable Adaptation to Global 474 Change. Newcastle, UK.

475 Wilby RL, Johnson MF, Toone JA. (2014) Nocturnal river water temperatures: Spatial and 476 temporal variations. Science of the Total Environment 482-483: 157-173..

477 Wright JF, Hiley PD, Berrie AD. (1981). A nine-year study of the life cycle of Ephemera 478 danica Müller. (Ephemeridae: Ephemeroptera) in the river Lambourn, England. Ecological 479 Entomology 6: 321-331. 
481 Table 1 Logistic regression model parameters $(\alpha, \beta$ and $\gamma)$, the amount of explained variance

$482\left(r^{2}\right)$ and the standard error of the estimate (SE) in both calibration and validation periods,

483 where SE is the RMS of error about the model, giving an estimate of the difference between 484 observed and modelled values.

\begin{tabular}{|l|c|c|c|c|c|c|c|}
\hline \multirow{2}{*}{ Site } & \multicolumn{5}{c|}{ Calibration (2011) } & \multicolumn{2}{c|}{ Validation (2012) } \\
& $\alpha{ }^{\circ} \mathrm{C}$ & $\beta^{\circ} \mathrm{C}$ & $\gamma^{\circ} \mathrm{C}$ & $r^{2}$ & $\mathrm{SE}{ }^{\circ} \mathrm{C}$ & $r^{2}$ & $\mathrm{SE}{ }^{\circ} \mathrm{C}$ \\
\hline Beresford & 23.4 & 15.0 & 0.1 & 0.85 & 1.3 & 0.83 & 1.9 \\
\hline Dovedale & 13.5 & 4.5 & 0.1 & 0.83 & 0.8 & 0.80 & 1.5 \\
\hline
\end{tabular}

485

486 
487 Table 2 Mean water temperature and GDDs in Beresford Dale and Dovedale. Annual (1 June 488 to 31 May each year) and seasonal GDDs are also shown for summer (June to July); autumn 489 (September to November); winter (December to February); and spring (March to May).

\begin{tabular}{|c|c|c|c|c|c|c|c|c|c|c|c|c|}
\hline \multirow[b]{3}{*}{ Year } & \multicolumn{6}{|c|}{ Beresford Dale } & \multicolumn{6}{|c|}{ Dovedale } \\
\hline & \multirow{2}{*}{$\begin{array}{c}\text { Mean } \\
\left({ }^{\circ} \mathrm{C}\right)\end{array}$} & \multicolumn{5}{|c|}{ Cumulative degree days } & \multirow{2}{*}{$\begin{array}{l}\text { Mean } \\
\left({ }^{\circ} \mathrm{C}\right)\end{array}$} & \multicolumn{5}{|c|}{ Cumulative degree days } \\
\hline & & ANN & JJA & SON & DJF & MAM & & ANN & JJA & SON & DJF & MAM \\
\hline $2005 / 06$ & 10.0 & 2697 & 1017 & 735 & 352 & 593 & 8.9 & 2305 & 749 & 616 & 398 & 542 \\
\hline $2006 / 07$ & 10.9 & 3038 & 1105 & 783 & 446 & 704 & 9.4 & 2495 & 781 & 643 & 461 & 610 \\
\hline $2007 / 08$ & 10.1 & 2749 & 967 & 692 & 455 & 634 & 9.0 & 2369 & 733 & 601 & 468 & 568 \\
\hline $2008 / 09$ & 9.8 & 2642 & 983 & 653 & 325 & 682 & 8.9 & 2293 & 738 & 578 & 377 & 599 \\
\hline $2009 / 10$ & 9.8 & 2615 & 1004 & 708 & 265 & 638 & 8.8 & 2260 & 745 & 610 & 332 & 572 \\
\hline $2010 / 11$ & 10.1 & 2705 & 998 & 647 & 329 & 731 & 8.9 & 2311 & 744 & 570 & 376 & 621 \\
\hline $2011 / 12$ & 10.3 & 2796 & 966 & 769 & 403 & 658 & 9.1 & 2483 & 731 & 668 & 432 & 682 \\
\hline $2012 / 13$ & 9.3 & 2426 & 958 & 614 & 334 & 520 & 8.4 & 2160 & 727 & 557 & 379 & 498 \\
\hline
\end{tabular}

490

491 
492 Table 3 The number (n) of male, female and small, unsexed mayfly and the percentage total 493 each constitutes each year. The mean, median, maximum and minimum total lengths for male, 494 female and unsexed individuals are included along with $p$-values from Mann-Whitney U tests 495 between male and female sizes. The number of GDD preceding emergence over 1 and 2 years 496 are quoted, along with the expected number of years emerging mayfly have developed over

\begin{tabular}{|c|c|c|c|c|c|c|c|c|c|c|}
\hline & \multicolumn{7}{|c|}{ Beresford Dale } & \multicolumn{2}{|c|}{ Dovedale } \\
\hline & & 2007 & 2008 & 2009 & 2010 & 2011 & 2012 & 2013 & 2012 & 2013 \\
\hline \multirow[t]{5}{*}{ Male } & $n$ & 70 & & & 48 & 61 & 279 & 101 & 53 & 56 \\
\hline & $\%$ & 20 & & & 32 & 27 & 48 & 47 & 27 & 19 \\
\hline & Mean & 18.0 & & & 14.4 & 11.1 & 14.7 & 10.8 & 18.7 & 16.0 \\
\hline & Max & 22 & & & 18.5 & 17 & 20 & 19 & 20.5 & 19 \\
\hline & $\min$ & 14.5 & & & 9 & 8 & 9 & 8.5 & 15.5 & 14 \\
\hline \multirow[t]{5}{*}{ Female } & $n$ & 132 & & & 101 & 163 & 308 & 78 & 60 & 120 \\
\hline & $\%$ & 37 & & & 68 & 73 & 52 & 37 & 30 & 41 \\
\hline & Mean & 23.7 & & & 18.1 & 11.5 & 20.5 & 13.8 & 24.3 & 22.4 \\
\hline & $\operatorname{Max}$ & 28 & & & 27 & 17.5 & 28 & 28 & 26.5 & 26 \\
\hline & $\min$ & 19.5 & & & 9.5 & 6.5 & 13 & 11.5 & 21.5 & 19.5 \\
\hline \multicolumn{2}{|c|}{$p$-value } & $<0.01$ & & & $<0.01$ & 0.496 & $<0.01$ & $<0.01$ & $<0.01$ & $<0.01$ \\
\hline \multirow[t]{5}{*}{ Unsexed } & $n$ & 156 & & & 0 & 0 & 0 & 34 & 86 & 115 \\
\hline & $\%$ & 44 & & & 0 & 0 & 0 & 16 & 43 & 40 \\
\hline & Mean & 3.6 & & & 0 & 0 & 0 & 7.5 & 4.3 & 6.5 \\
\hline & Max & 5.5 & & & 0 & 0 & 0 & 8 & 7.5 & 10.5 \\
\hline & $\min$ & 1 & & & 0 & 0 & 0 & 6 & 1 & 2.5 \\
\hline \multicolumn{2}{|c|}{ 1-year GDD } & 3038 & 2749 & 2642 & 2615 & 2705 & 2796 & 2426 & 2483 & 2160 \\
\hline \multicolumn{2}{|c|}{ 2-years GDD } & 5735 & 5787 & 5391 & 5257 & 5320 & 5501 & 5222 & 4794 & 4643 \\
\hline \multicolumn{2}{|c|}{ Expected life-cycle } & 2 & & & 1 & 1 & 1 & 2 & 2 & 2 \\
\hline
\end{tabular}


Figure 1 The River Dove catchment showing invertebrate (green circles), LUTEN (red 500 circles) and Environment Agency river gauge (black circle) sites. Grey indicates limestone

501 outcrop; unshaded is millstone grit. Insets show Beresford Dale and Dovedale invertebrate 502 sampling areas and closest LUTEN sites.

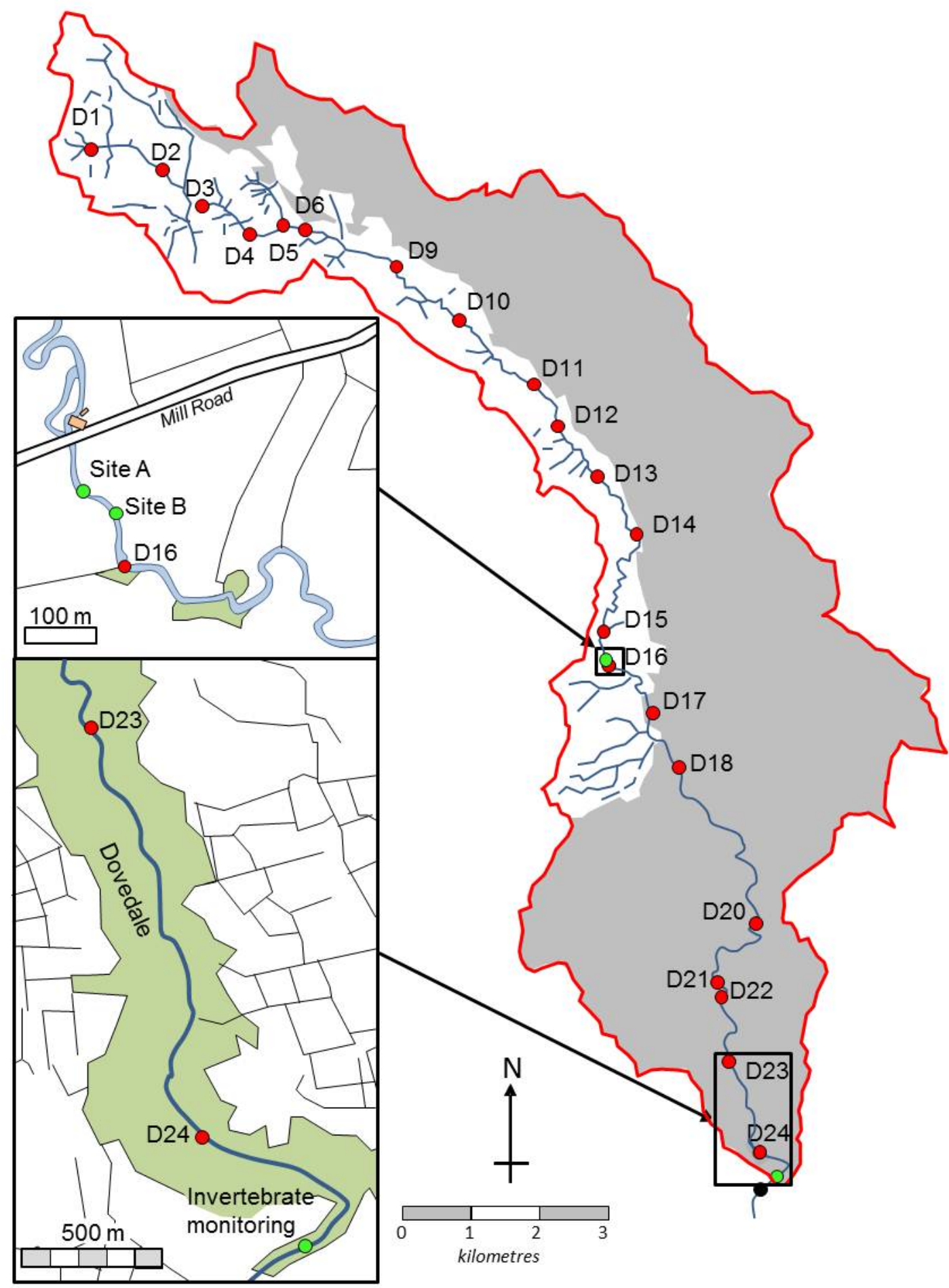


504 Figure 2 Schematic of the E. danica life-cycle. From hatching, larvae develop as they 505 accumulate heat during their aquatic stage. Females grow larger than males over the same 506 period and this variance widens as heat accumulates. Emergence occurs in early-June. Year 2 507 shows two cohorts with distinct male and female size distributions in one, and a group of 508 small mayfly in their first year of growth. Year 4 shows a single year cohort, with mayflies 509 about to emerge all of moderate size and males and females of similar dimensions. The transition between one and two year cycles (Year 3) also has no peak in small mayfly.

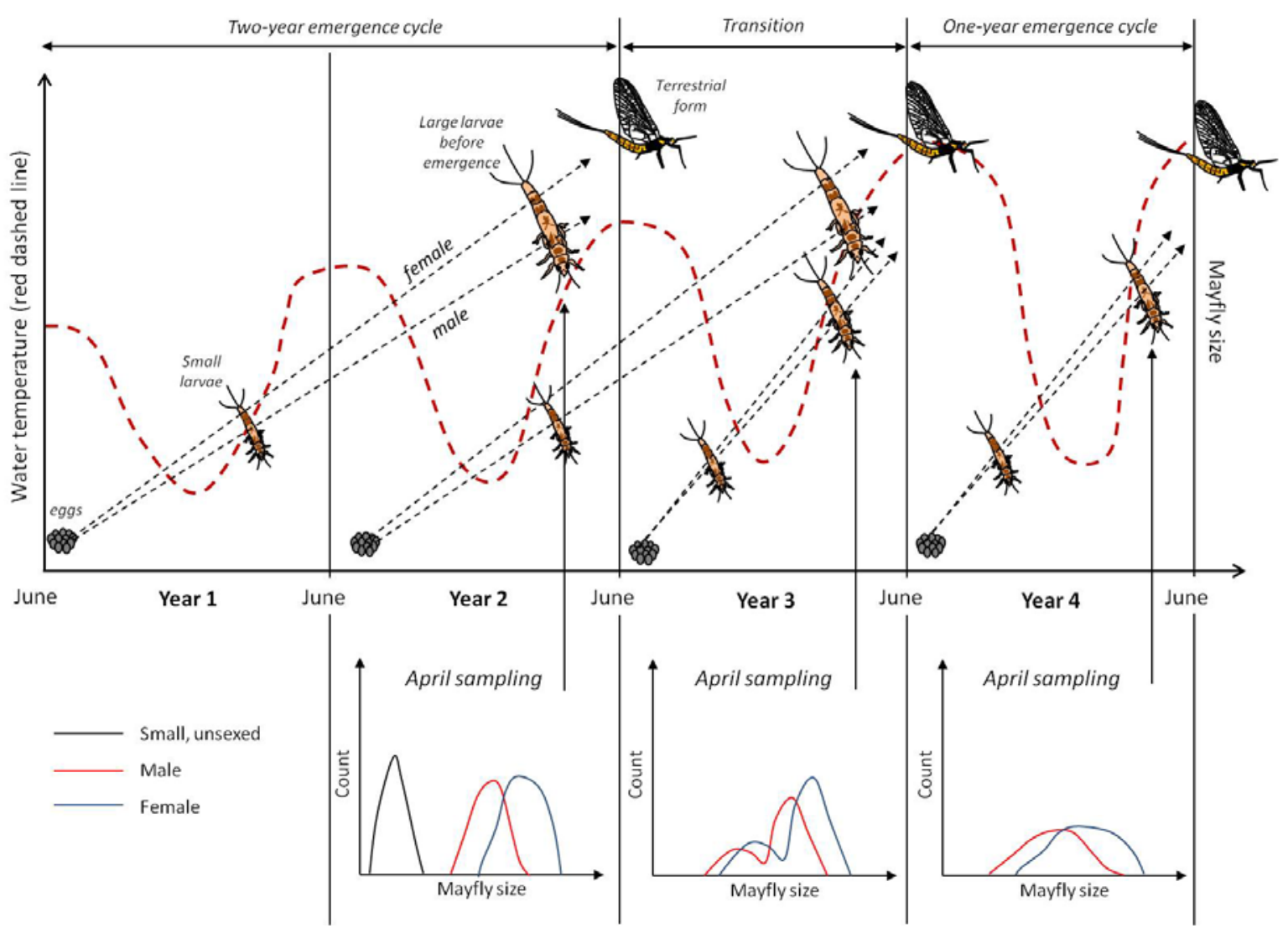


513 Figure 3a) Hind cast daily-mean Tw at Beresford Dale (red) and Dovedale (black) for June

5142005 to May 2013. Model residuals are shown for Beresford Dale (pink) and Dovedale (grey)

515 for the period with LUTEN data (March 2011 to May 2013). b) GDDs for years beginning in

516 June 2005 to May 2013 at Beresford Dale (red) and Dovedale (black) assuming minimum

517 growth threshold for male E. danica $\left(2.6^{\circ} \mathrm{C}\right)$.

a) 20

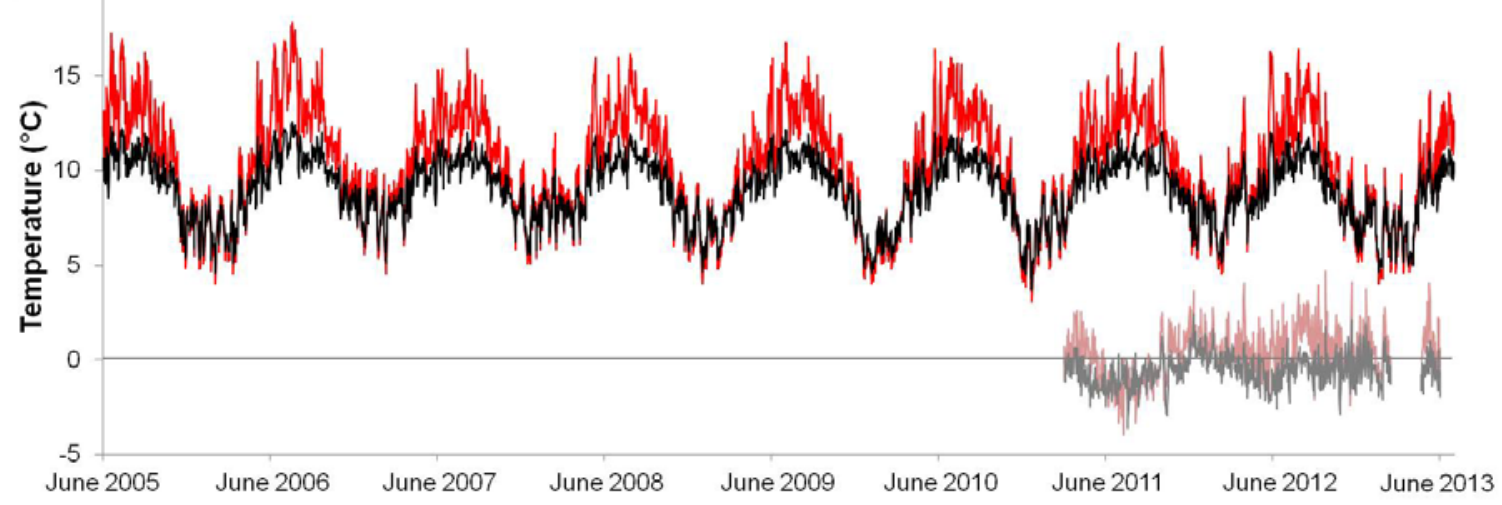

b)

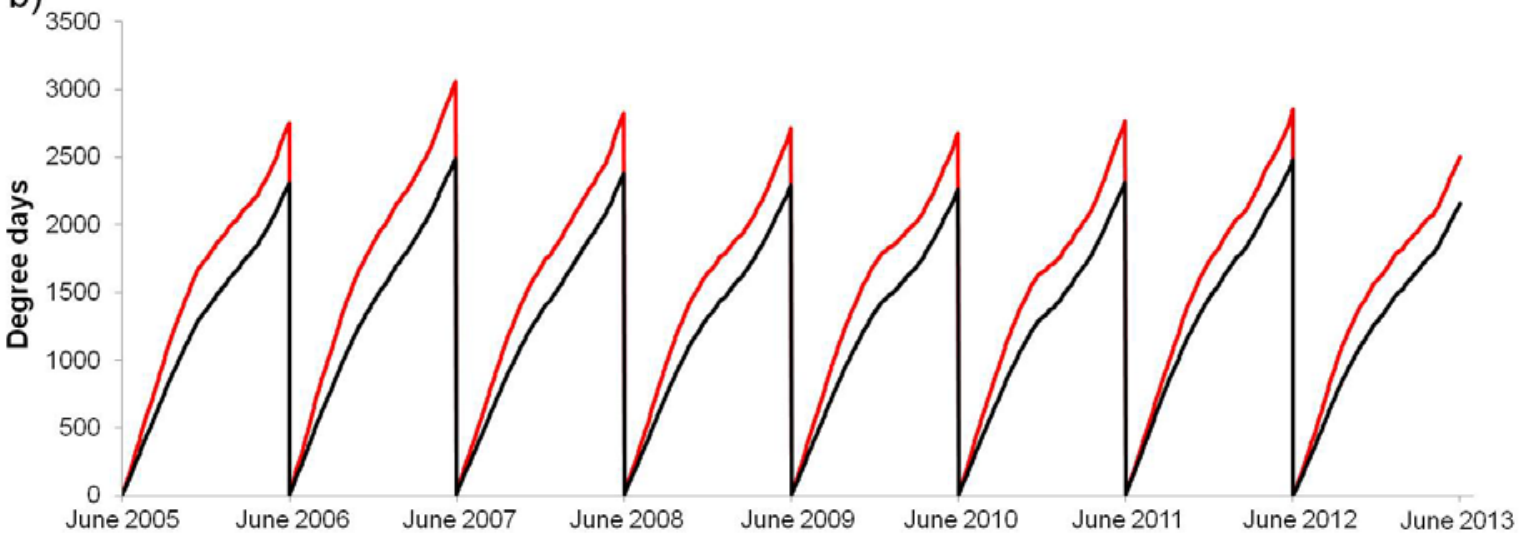

518

519 
520 Figure 4 Estimated annual mean temperatures at D16 (Beresford) based on 1000 replicates of 521 one sample per month drawn from 15-minute LUTEN data for the hours 08:00 to 18:00. The

522 overall LUTEN mean is shown by the vertical line. Shading denotes standard deviations from

523 the mean.

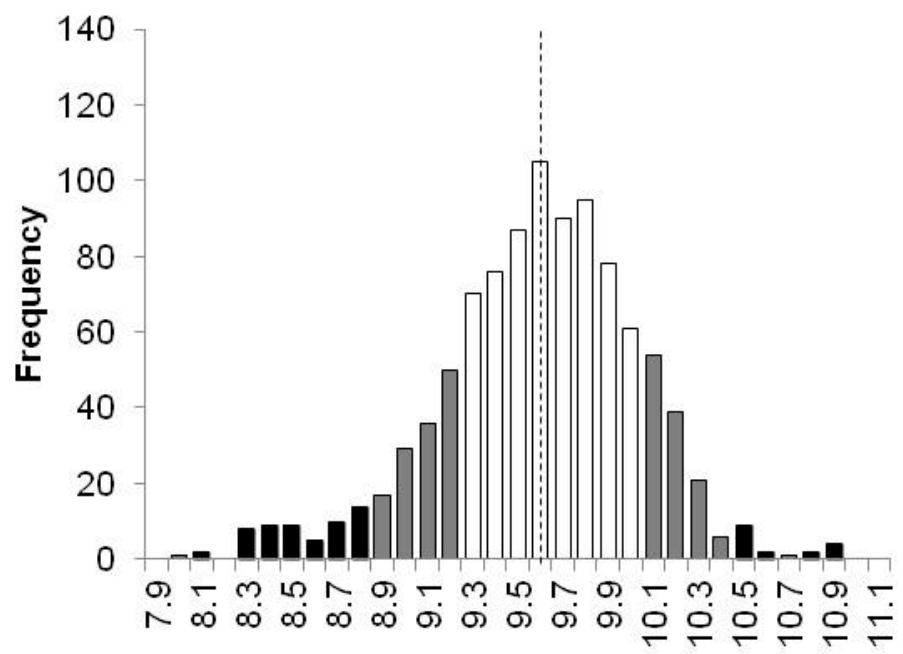

Annual mean estimate $\left({ }^{\circ} \mathrm{C}\right)$

524

525 
526 Figure 5 Number and size of mayflies caught in Beresford Dale in a) April 2007 and b) each

527 April from 2010 to 2013.

a) 30

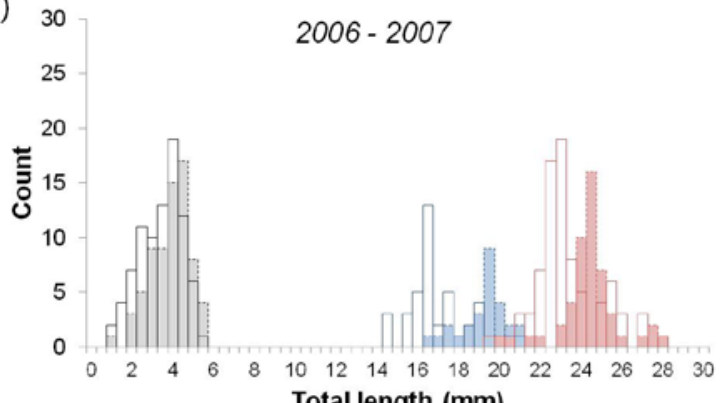

b)

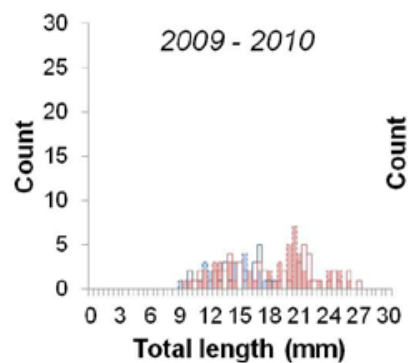

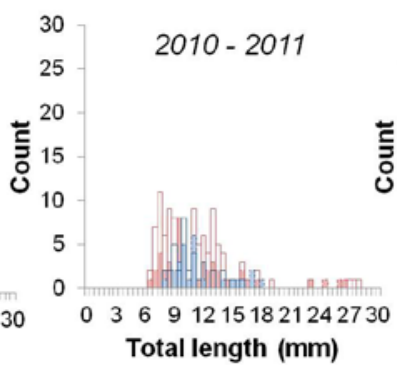
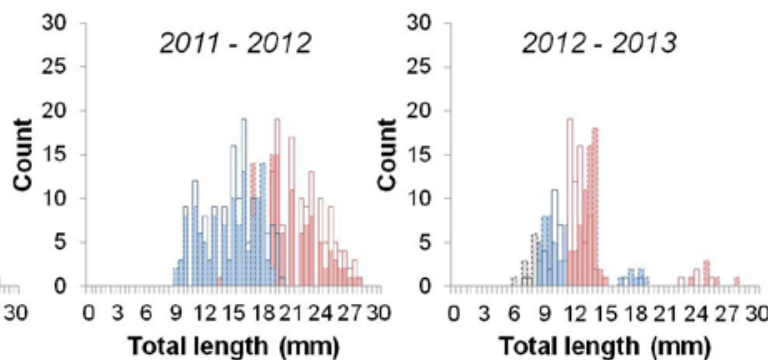

$\square$ Female site $A$

Unsexed site A

Male site $B$

Female site $B$

i.. Unsexed site B 
530 Figure 6a) Annual GDDs for growth threshold $2.6^{\circ} \mathrm{C}$ (red line) and number of small mayfly

531 (<7 mm) sampled each year (purple line) in Beresford Dale. b) Average length of female (left)

532 and male (right) E. danica with 95\% confidence intervals sampled in Beresford Dale (blue)

533 and Dovedale (green). The red line indicates GDDs at Beresford for growth threshold of

$5342.6^{\circ} \mathrm{C}$. All years were statistically distinct for females.

535
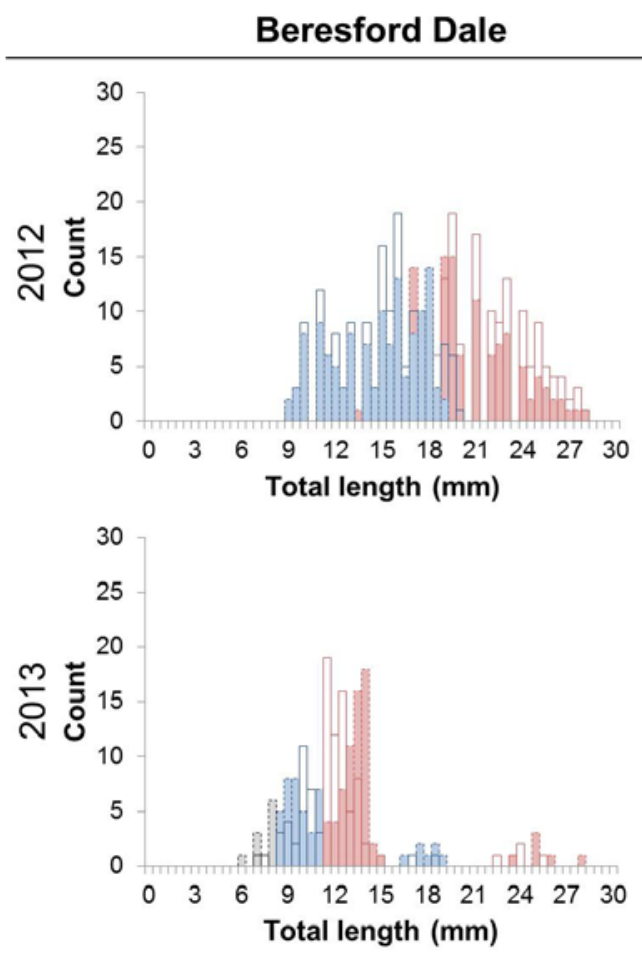

Dovedale
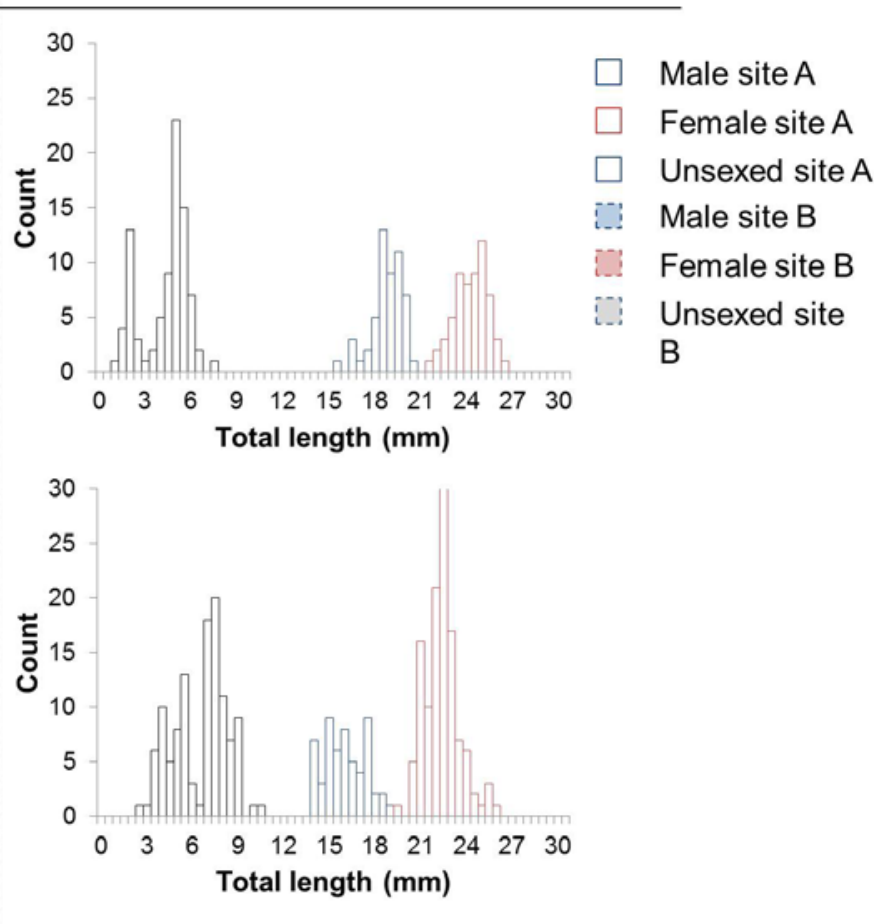

536 
537 Figure 7 Number and length of E. danica caught in Beresford Dale (left) and Dovedale (right) 538 in 2012 and 2013.
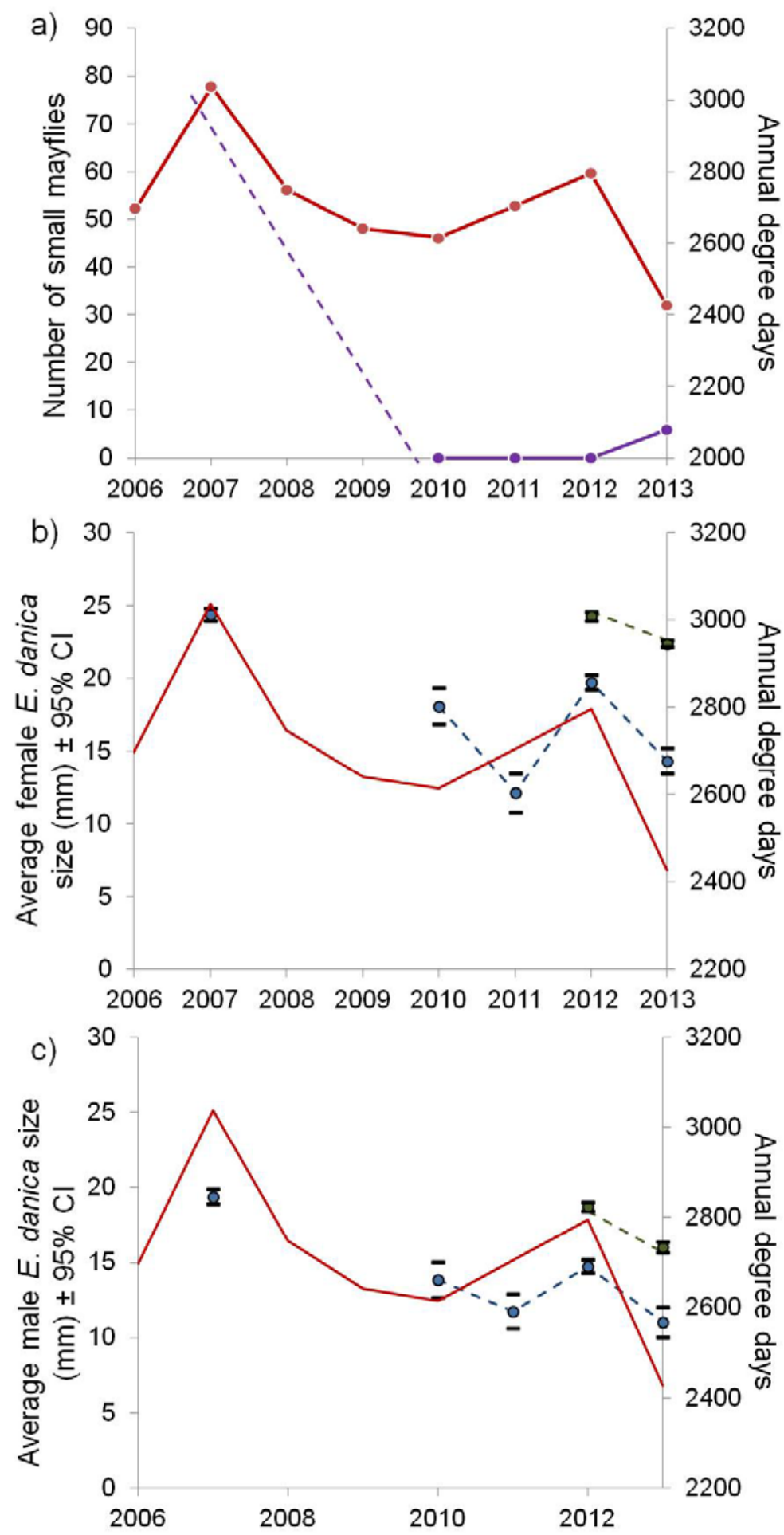